\title{
THE IMPACT OF PROJECT MANAGER ON PROJECT SUCCESS - THE CASE OF ICT SECTOR
}

\author{
BÁLINT BLASKOVICS ${ }^{1}$ \\ ${ }^{1}$ Assistant Professor, Strategy and Project Management Department, Corvinus University Budapest \\ E-mail: balint.blaskovics@uni-corvinus.hu
}

\begin{abstract}
The project management literature on project success is rich. Numerous papers focus on the evolution of the understanding of project success, identification of success criteria and critical success factors. Critical success factors increase the potential for achieving project success, while project success can be evaluated with the help of success criteria. Although the interrelationships between critical success factors and success criteria are rarely analyzed, yet there is a strong demand for it. The aim of this paper is twofold. One of the aims is to identify the impact of one of the critical success factors, the project manager's project management attitude on project success. The other aim is to highlight the interrelationship between the project manager's personal characteristics and project management attitude and leadership style, which are three critical success factors. These aim to address the shortcoming mentioned above, which is considering the lack of the interrelationships between critical success factors and success criteria. The research outcomes are drawn from qualitative field research at the Hungarian subsidiaries of multinational companies operating in the ICT sector.
\end{abstract}

Keywords: project success, success criteria, critical success factors, project manager's knowledge, leadership style

JEL code: M19 


\section{Introduction}

Organizations spend high amount of money on projects. By the new millennium, the total spending on projects reached almost $20 \%$ of the world's GDP (Bredillet 2007). However, the success rate achieved on projects is very low. Only a bit more than one-third of the projects are finished successfully (Fehér 2009; Standish Group 2013), while the rest do not reach the predefined parameters. The situation is worse in the IT sector, where the success rate is onethird (Standish Group 2013), however, the newly introduced methodologies, such as agile project management, have increased this rate in the past few years. Both cost and time overruns are very common to IT projects, while more than $20 \%$ of these projects are cancelled before even commencing (Lee-Kelley - Loong 2003).

The Standish Group (2013) highlighted the most important reasons for failure: a) inappropriate project scope definition; b) inappropriate project communication; c) lack of appropriate project management competencies. The study also draws the attention to the importance of the organizational characteristics as well, like the applied project management methodology, project management expertise, tools and infrastructure.

Taking the amount of money spent on project into account, achieving project success is a must for organizations (cf. Schaltegger 2011). To achieve this, it is required to clearly understand the success criteria and the critical success factors, as well as the relationship among them.

Various authors have already identified certain critical success factors, while Fortune and White (2006) provide a comprehensive overview of them. Among others (see e.g. Görög 2003; Müller - Turner 2010; Yang et al. 2011), they pointed out the key role of the project manager to achieve success on projects. Although the literature highlights the relationship between the project managers' managerial features and the likely project success, yet an indepth analysis was not carried out.

The primary aim of the paper is revealing the interrelationship among project success expressed in terms of success criteria and the project managers' project management attitude. In order to do so, there is a need for highlighting the interrelationship between personal features, and leadership style and attitude. 


\section{Literature review}

Considering the defined aims of the paper, there is a need for providing a review of the literature on the understanding of project, the phenomenon of project success, personal characteristics, leadership style, and the project management attitude of project managers.

\subsection{Understanding of a project and project management}

Understanding the concept of a project has developed considerably in the last decades. For a long time, projects were considered as unique tasks (see e.g. Olsen 1971). Lundin and Söderholm (1995) realized in the mid 90s that projects are temporary organizations. Cleland (1994) states that projects are building blocks of strategic implementation, i.e. projects create the beneficial changes needed for organizations. Nowadays, projects are unique tasks, temporary organizations and strategic building blocks at the same time. Görög (2013: 9) defines them as follows: '...projects are one-time, complex and unique set of activities carried out in a project organization with time and budget constraints and they have a predefined project result to be implemented.'

The role of project manager has developed in accordance with the understanding of concept of project success (see e.g. Görög 2002; 2013). Earlier, when projects were defined as unique tasks, project managers were supposed to focus on the process of the project, thus managing the implementation process considering the project results, and the time and cost constraints. As the understanding of the concept of a project widened, the role of the project manager also advanced. The management of stakeholders and the delivery of the beneficial change became part of his/her role. These days the most important roles are as follows: planning the projects, implementing the plan, managing stakeholders and delivering the beneficial change (see e.g. Fekete - Dobreff 2003; Project Management Association 2006). Thus project management can be considered as an application of knowledge, skills, tools, and techniques to project activities to meet the project requirements (Project Management Association 2006: 24).

\subsection{Understanding of project success}

Due to the increased complexity of project and project management, project success also became a complex phenomenon, which may be considered both from input- and outputoriented perspective. The output-oriented perspective evaluates project success by means of success criteria (see e.g. Cooke-Davis 2002). While the input-oriented perspective analyzes 
the factors contributing to project success by means of critical success factors (see e.g. Fortune - White 2006).

The understanding of project success has developed during the decades considerably, and this process was in accordance with the understanding of the concept of project and project management. At the beginning, papers on project success were focusing on the classical project triangle (time, cost, quality). Later, this was enhanced by considering stakeholder satisfaction and the strategic aspect of the client. This development requires the consideration of the interrelationships among the components of the project success: the success criteria and the critical success factors (Judgev - Müller 2005; Mészáros 2005).

\subsubsection{Success criteria}

Success criteria are those base values, on which project success can be evaluated (Görög 2013). When defining the appropriate success criteria, two important factors should be considered (based on Judgev - Müller 2005):

- Holism: the evaluation model should contain every relevant criterion, against which, a project success can be properly measured.

- Realism: the model should not divert the actual outcome, i.e. a model should not classify a successful project as unsuccessful and vice versa.

Since both project and project management are complex phenomena, success criteria should also reflect this. In the course of defining the proper success criteria, it is also necessary to consider the understanding of the concept of project and project management. This means that from the point of view of project success, both the project result and project management should be considered. Project result success focuses on the project result, whether the project result, which was created by the project, satisfied the desires of the most important stakeholders. Project management encompasses managing the implementation of the project, the stakeholders and the delivery of beneficial change. In this way, its success focuses on the appropriate use of resources and appropriate management of stakeholders. Thus project management success encompasses the efficiency of project delivery, while project success embodies the effectiveness of project delivery.

As a result, the efficiency of the project completion (implementation of the project) and effectiveness of the project completion (managing the project team and delivering the beneficial change) should be measured (Baccarini 1999; de Wit 1988; Görög 2013). The first 
term can be measured against the project triangle (see e.g. Cooke-Davis 2002; Görög 2003), the latter term can be measured against client satisfaction and stakeholder satisfaction (see e.g. Atkinson 1999; Baccarini 1999; Görög 1996).

Thus an appropriate model should evaluate the project completion (efficiency) and the project result (effectiveness) containing the following criteria (see e.g. Atkinson 1996; Görög 2003; Project Management Institute 2010; Shenhar et al. 2001): project triangle (time, cost, and quality), client satisfaction, and stakeholder satisfaction. This triple criterion system provides a complete, thus a holistic approach.

Besides this triple criterion system, there are alternative evaluation models, like the key performance indicator (KPI) based or financial indicator-based (like NPV or IRR) evaluation models (see e.g. Toor - Ogunlana 2010; Yu et al 2005). These models can be very effective in certain projects, but they face serious shortcomings when they have to evaluate projects which are hard to quantify. Based on that, these models cannot be considered holistic.

Besides holism, a criterion system or a model should satisfy realism as well. From this point of view, two kinds of approaches exist in the literature. The non-hierarchical approaches (see e. g. Atkinson 1999; Project Management Institute 2010; Wateridge 1997) and hierarchical approaches (see e.g. Baccarini 1999; Cooke-Davis 2002; Görög 2003). The first one assigns equal weight to the criteria, while the second distinguishes the criteria and they can compensate each other to a certain extent. There are projects which exceeded the time and cost constraints and were still found to be successful (see e.g. Kun 2005); in this way hierarchical approaches are appropriate.

Thus an evaluation model should be a hierarchical model containing the following criteria (Görög 2003): project triangle (time, cost, quality); client satisfaction; and stakeholder satisfaction.

\subsubsection{Critical success factors}

Besides the output-oriented perspective, the input-oriented perspective, i.e. the critical success factors should also be considered. Critical success factors are as follows (Boynton - Zmud 1984: 17): 'those few things that must go well to ensure success for a manager or an organization.'

The evolution of critical success factors is very similar to the evolution of understanding of project success (Judgev - Müller 2005). Until the mid 90s, the literature mainly focused on the project triangle (see e.g. Fortune-White 2006), as of today the focus has widened, and the 
range of critical success factors became broader. Nine groups can be created, which are as follows (based on Blaskovics 2014; Fortune - White 2006; Görög 2003; Yang et al. 2011):

- clarity of the underlying strategic objective of the project;

- scope definition of the project;

- continuous communication amongst the project team members (including the user's involvement and the support of the senior management);

- reliability of the project triangle and the availability of the resources needed;

- competency of the project manager and his/her leadership style;

- competency of the project team and the team's motivation;

- risk management;

- change management;

- organizational and environmental characteristics.

Although critical success factors or groups are good to draw the attention to those factors, which bear the importance for achieving project success, they have serious shortcomings (SCs). These are as follows:

- SC\#1: The importance of the critical success factors may vary throughout the delivery of the project and this is not taken into consideration (Fortune - White 2006).

- SC\#2: The interrelationships among the critical success factors are not taken into consideration, although the interrelationships could be more important than the factors themselves (Fortune - White 2006).

- SC\#3: Projects are unique and one-time set of activities, thus generally applicable critical success factors cannot be identified (Görög 2003).

- SC\#4: Critical success factors usually consider project success as homogenous phenomenon (Fortune - White 2006).

From the nine critical success factor groups a few clearly enhance the whole lifecycle of the project. One of these is the competency of the project manager and his/her leadership style. A project manager has a considerable role in all phases of project (Müller - Turner 2007). His/her knowledge and competency are found to be important to achieve project success. 


\subsection{Project management capabilities}

In the literature, many researchers have analyzed the project managers' knowledge areas (see e.g. Ahadzie 2014). A project management capability is a knowledge area that a project manager should possess in order to achieve project success (Görög 2013). The evolution of the required capabilities is in line with the evolution of understanding the concept of project. When projects were considered as unique tasks, the focus was on the project management quantitative tools (see e.g. Olsen 1971). As the understanding expanded, the spectrum of required knowledge areas also broadened. In order to manage project properly, project managers should own capabilities which are used for motivating, influencing and integrating stakeholders (see e.g. Pinto 2000), and delivering beneficial change (see e.g. Görög 2002; 2013). Cleland (1994) summarizes the three most important capability areas that a project manager should possess: (1) the technical capabilities: those that relate to the technical part of the project; (2) the human capabilities: those that relate to the management of stakeholders; and (3) the project related capabilities: those that relate to the project management knowledge. These three basically refer to possessing all the tools, techniques and practices which are in connection with the professional knowledge of project management.

Each capability area can be expressed in a deeper manner, although this paper focuses only on the third group. Project related capabilities embody the professional content, i.e. the required competencies of project management (Cleland 1994). Although there are other approaches (see Görög 2013), this paper relies on Cleland's (1994) concept. Cleland (1994) defines three competency elements, which are as follows: a) knowledge: familiarity with the project management toolkit; b) skill: the ability to apply the knowledge (project management tools, techniques and practices); c) attitude: the approach of the project manager towards managing projects. This attitude implies two main aspects (Görög 2013). One of them is the way in which the project manager applies the project management toolkit. It implies whether or not a project manager takes into consideration the characteristics of the project context, when he/she makes a decision on using different project management tools or he/she follows a certain kind of best practice regardless of the project context. The other aspect relies on the understanding of project and consequently the understanding of managing projects. If a project manager considers the project as a unique task, then the project management means managing the implementation process of this task, which places the focus on planning and control the implementation process. If the project is considered to be a temporary organization, then the project management means managing the temporary organization, which places the focus on the management of stakeholders, especially the project team. If the 
project manager considers the project as strategic building block, then the project management is interpreted as delivering the beneficial change, which puts an emphasis on strategic project scope definition, proper communication with the client, and optimization based on the changes. Of course, these project management attitudes can be simultaneously applied.

The paper focuses on the latter approach of project management attitude, which relies on the understanding of project.

\subsection{The project manager's leadership styles}

Parallel to the required knowledge of the project manager and in accordance with the previously identified nine groups of critical success factor; the leadership style also bears great importance (see e.g. Yang et al. 2011). In the 60s, the leadership style approaches were focusing on the relationship of project managers towards implementing plans and managing team members (see e.g. Fiedler 1964). This idea was later enhanced, for example by the democratic, dictatorial, charismatic leadership style, or the leadership style based on the context of the project (see e.g. Blaskovics 2014; Turner 2009). Müller and Turner (2007; 2010) provide a comprehensive overview of the leadership styles, and identified the following categories:

- Leadership based on trait: the project manager should possess certain personal characteristics (like confidence), which are needed to manage successfully.

- Leadership based on behaviour or style: different projects require different leadership styles. Due to this, the project managers should use those attributes and to that extent which are required for the given project (like empowerment).

- Leadership based on contingency: it is vital to identify the characteristics of the project and the project manager should adapt to this.

- Leadership based on charisma or vision: it is composed of two categories. The first category emphasizes the importance of personal characteristics and leading by examples. The second one emphasizes the importance of realizing the plans via bonuses and reaction to deviations.

- Leadership based on emotional intelligence: emotional intelligence is the key for project success, thus project managers should apply it during the management of projects. 
- Leadership based on competency: the project manager should possess certain competencies (e.g. emotional competencies) in order to achieve project success.

\subsection{The project manager's personal characteristics}

Besides the leadership style, the project manager's personal characteristics are also highly important from the point of view of contribution to project success (see e.g. Fortune - White 2006). Numerous characteristics were identified (see e.g. Pant - Baroudi 2008; Pettersen 1991), although most of them have an overlap with other managerial characteristics (see e.g. International Project Management Institution 2006, Project Management Association 2010). Since project management is different from other management areas (see e.g. Görög 2003), project managers' should possess unique characteristics. Görög (2013) summarizes these based on the literature, which are as follows:

- Optimism: projects are one-time; there is no potential for correction if the project is unsuccessful.

- Team-building ability: there is a requirement for integrating people coming from different department with different background.

- Motivational ability: a project manager should be able to motivate his/her team (cf. Pinto 2000).

- Trust building ability: trust is inevitable for managing people.

- Emotional intelligence: there is a demand to possess certain amount of empathy in order to feel and understand project team members' problems. Without this, the project manager might not manage the project or solve problems in the way as the project team members' desire or would be optimal.

- Improvisation: without the proper improvisational ability, the project manager cannot react properly to the unpredictable problems.

\subsection{Research considering the interrelationships between critical success factors and success criteria}

Although research primary focuses on identifying critical success factors or success criteria (cf. Görög 2013; Fortune - White 2006; Judgev - Müller 2005), some papers do focus on the 
alignment of critical success factors and success criteria, or considering the interrelationships among them.

The model of Fortune and White (2006) can be an example for the first. It is based on the Formal System Model, dividing the project environment into subsets and defining tasks within the subsets. The model considers the potential impact of critical success factors on project success (via the subsets and tasks). However, the specific, quantitative success criteria cannot be identified directly, and the interrelationships are not considered. The other example for the alignment is the Project Excellence Model (International Project Management Association 2014; Westerfeld 2003) which analyses the project from the aspect of the organizational success criteria and project result related success criteria. However, the lack of detailed analysis on the impact of critical success factors on success criteria can still be identified, just like the lack of interrelationships among each other.

Parallel to the efforts aligning success criteria with critical success factors, the interrelationships were also considered. Two groups can be identified. The first is focusing on the interrelationships among the critical success factors (see e.g. Yang et al. 2011), the other is focusing on the impact of a critical success factor on a success criteria (see e.g. Jha - Iver 2007) or project success (see e.g. Bryde 2008). This research mainly concentrates on one critical success factor and the impact of it on another critical success factor or success criteria. However, both are rarely analyzed. An example for the analysis of both is Cserháti and Szabó (2014), where six critical success factors and two success criteria are considered. Their impact and interrelationships were analyzed with the help of a detailed and complete quantitative analysis.

The most important advantage of these papers is to eliminate one or more shortcomings of the critical success factors; although the number of them is still relatively low to the papers aiming to identify critical success factors (cf. Fortune - White 2006), and in most cases the spectrum of the analysis is very limited.

\subsection{Outcomes of the literature}

One of the outcomes of the literature was that the appropriate evaluation model for measuring project success is a hierarchical model consisting of the project triangle, client satisfaction and stakeholder satisfaction. This is due to the two factors discussed earlier, realism and holism.

The other outcome is that the critical success factors have considerable shortcomings. One of them is neglecting the variable importance of critical success factor. However, the project 
manager's personal characteristics, project management attitude and leadership style are constantly important.

The third outcome of the literature review was that the different competencies, leadership styles and personal characteristics were identified. At the same time, the interrelationships between project success and the previously mentioned features are rarely analyzed in a detailed manner. Instead, the authors focus on defining a set of personal characteristics, leadership styles and competencies.

\section{The research and the research method}

The research had a twofold aim. One was to reveal the impact of the project management attitude's on all the three dimensions of project success: project triangle, client satisfaction and stakeholder satisfaction. The other aim was to reveal the existence of the personal characteristics' impact on project management attitude and leadership style. These aims are encapsulated in the research model presented in Figure 1.

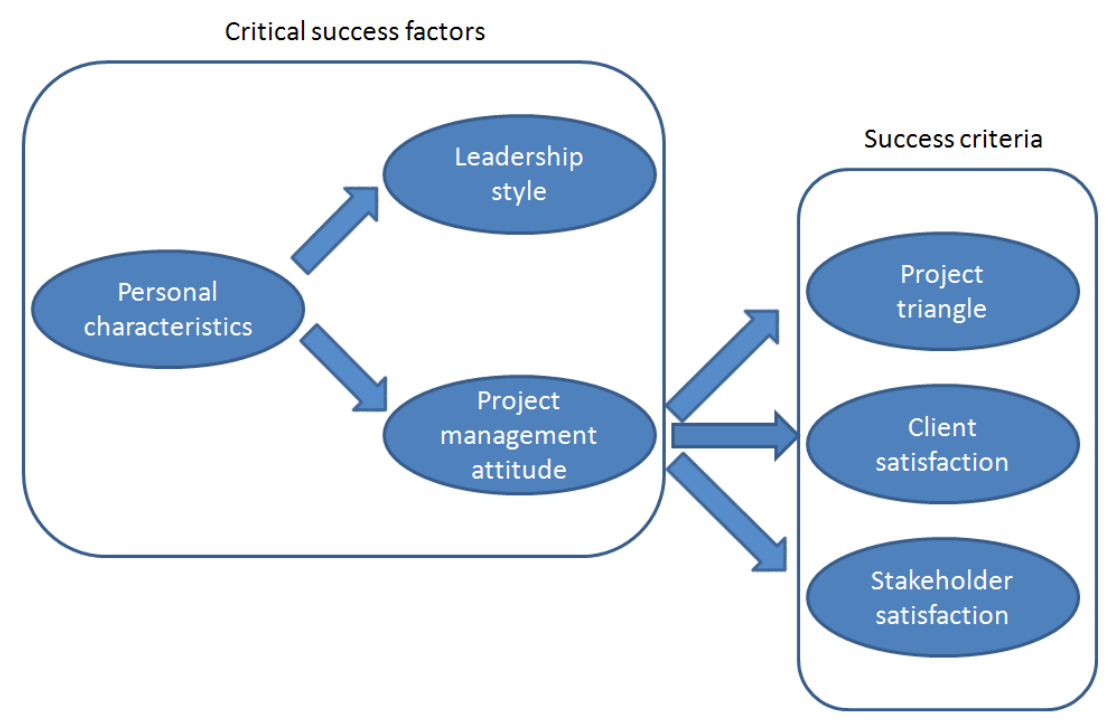

Figure 1. Research model

Source: author

As it was highlighted in the literature review, critical success factors have considerable shortcomings. Throughout the research, I accepted propositions by the means of which these 
shortcomings might be eliminated. Although the importance of critical success factors may vary during the lifecycle of the project, the project manager has an active role to influence the potential success throughout the project. Even if the interrelationships are not taken into consideration, I took the impact of personal characteristics on project management attitude and leadership style into consideration. Since there is no potential for identifying generally acceptable critical success factors, during the research I did not intend to identify a critical success factor. Even if critical success factors usually consider project success as a homogenous phenomenon, I expressed project success in terms of success criteria.

Based on the research aims, the following research questions were formulated:

- Does attitude have an impact on project success measured against success criteria?

- Do personal characteristics have an impact on project management attitude and leadership style?

\subsection{Detailed discussion of the research method}

In order to achieve the aims of the research, it had two distinguished parts: desk research and a field research.

In the course of the desk research, the literature related to project success, critical success factors, success criteria, leadership styles, project management capabilities, project manager' project management attitude and project manager's personal characteristics were revealed. The aims of this part were to identify the appropriate approach to project success, reveal the existing project manager's project management attitudes, leadership style categories and those personal characteristics which bear great importance for project managers. Based on these, the questions for the interviews could be formulated.

The aim of the field research was also twofold. One was to reveal the impact of the project managers' project management attitude on project success, expressed in terms of the success criteria. The other aim was to reveal the impact of personal characteristics on project managers' project management attitude and leadership style.

In the course of the field research a qualitative research methodology, semi-structured interviews were used, which lasted 45 to 60 minutes (Babbie 1994; Creswell 2003).

The unit of analysis was the project managers in Hungarian subsidiaries of multinational companies operating in the ICT sector. The ICT sector is turbulent, rapidly changing, 
innovative and knowledge intensive sector, where the technology lifecycle is usually noticeably short. These are the reasons that the satisfaction of workers is important for the companies (cf. Blaskovics, 2014; Nemeslaki et al. 2004). This potentially has an impact on leadership style and project management attitude, which increased the demand for an adequate project manager. However, this paper focuses on the project managers' features, not the organizational or industrial characteristics.

Five companies were selected, which have a leading position in the industry. The name of the companies cannot be revealed due to confidential reasons. Twenty-five project managers were selected (with the help of the Project Management Offices, the PMOs or with the help of lead project managers). A sample of twenty-five project managers (PM) is seen as sufficient. This is due to they have common knowledge and common understanding about project management, they work in the same sector and have to absolve trainings and adapt the companies' project management standards used/developed by the given companies. Based on these, they possess an almost homogenous knowledge and understanding about project management.

\subsubsection{The interviews}

The interviews with the PMs had three steps. In the first step, the PM's knowledge was mapped. If a PM does not possess an appropriate PM knowledge, then he/she cannot have an appropriate project management attitude.

In the course of the second step, the PM's project management attitude was identified and then the impact on project success in terms of three success criteria was revealed. Throughout this step, the project manager first had to describe his/her project management attitude. Then the PMs had to describe whether the applied project management attitude had an impact on project success in terms of each criterion, or not. The latter part was checked by asking how it had an impact on each criterion, thus the false or inappropriate answers could be identified. This way the independent variable was the project manager's project management attitude, while the dependent variables were the three success criteria. The aim of this step was to reveal the existence of the impact itself, neglecting the scale of the impact.

During the third step, the PM's leadership style and personal characteristics were analyzed. First, the PM should list those elements he/she thought contributing to his/her current leadership style and project management attitude. They were also asked whether their 
personal characteristics were changed or not during their project management career (special focus on those six which were mentioned in the literature review). If there were alterations, they were asked to describe the change by words or assign a score to the before-change state and to the current state. Later on, they had to describe the leadership style before and after the change. Finally a question was deployed to check, whether the personal characteristics have an impact on the leadership style and project management attitude, or not. The aim of this step was to reveal the impact of personal characteristics on leadership style and project management attitude. The scale of the impact was out of the scope of the research. In this step of the research, the leadership style and project management attitude were considered the dependent variables, and the personal characteristics were considered the independent variable. Throughout this step, two phenomena were also considered. The first is the other elements which had an impact on the leadership style and project management attitude. The research was not focusing on identifying every element; the aim was to reveal the impact of the personal characteristics on them. The second phenomenon was the false correlation. Even if both the personal characteristics and leadership styles changed or both personal characteristics and leadership style remained static, it could happen that other element cause the impact. Considering these potential phenomena, it was recommended to ask the first and third question.

\section{Discussion}

The first step of the field research was the mapping of project management knowledge owned by PMs. Only one of the PMs did not possess the required knowledge highlighted in the previous parts. He started his PM career two weeks before the interview took place, while the others had a solid knowledge in the field of project management. Many project managers (more than $40 \%$ ) possessed a certain certification (Six Sigma, PMP or PRINCE2). The remaining PMs also had solid project management knowledge; however, they did not have a certification. The tools and techniques known and used by the uncertified PMs were matched with the tools and techniques that are required for being certified (cf. Görög 2013; Project Management Institute 2010). 


\subsection{Identification of the project management attitude of project managers'}

The aim of the first part of the second step was to identify the project managers' project management attitude. The most common answer was the 'stakeholder-centric' (especially project team-centric) attitude, which reflected the temporary organization based attitude towards projects, thus managing the temporary organization based attitude towards managing projects. The other common answer was the 'strategic-oriented approach', which reflected the strategic building block based attitude towards projects, thus delivering the beneficial change based attitude towards managing projects. Besides these, there were other attitudes that were mentioned by two PMs: 'planning-based approach' and 'technocratic approach'. These two approaches both reflected the unique task based attitude towards projects, thus managing the implementation process based attitude towards managing projects. The highlighted attitudes were categorized by the researchers in accordance with the following considerations. When the interviewee mentioned the primary importance of corporate strategy and/or the goal achieved by the client, then the project manager was considered to have a 'strategic-oriented' project management attitude. If the project manager found the project team and/or stakeholders primary important, then the project manager was considered to have a 'stakeholder-centric' project management attitude. If the interviewee relied primarily on planning, decomposing the project into a well-built process and realizing the plans, then the project manager was considered to have a 'planning-based' project management attitude. And if the PM approached the project from the technical side of it (like the tools and assets that should be used in the project in order to deliver the project result), then the project manager was considered to have a 'technocratic' project management attitude. The interviewees reinforced the categorization specified by the researcher. The outcome is encapsulated in Table 1.

Table 1. Research outcomes of the project managers' attitude

\begin{tabular}{|l|l|}
\hline The adopted project management attitude & \multicolumn{1}{|c|}{ Underlying reason } \\
\hline Strategic-orientated & $\begin{array}{l}\text { The focus is on the corporate strategy during managing } \\
\text { projects }\end{array}$ \\
\hline Stakeholder-centric & $\begin{array}{l}\text { The focus is on the primary stakeholders during } \\
\text { managing projects }\end{array}$ \\
\hline Technocracy & The project is approached from a technical orientation \\
\hline Planning-based & The focus is on the adequate planning and control \\
\hline
\end{tabular}




\subsection{Impact of project management attitude on project success}

The next part of the research was identifying the impact of the project management attitude on project success expressed in terms of the success criteria encompassed in the hierarchical model. Each of the PMs' project management attitudes had an impact on the project triangle, especially on time and quality. Stakeholder-centric project managers relied on tools like motivation, communication and they tried to make the project team understand the importance of the project tasks. Strategic-oriented project managers took the completion time and the required quality into consideration in accordance with the goals of the client organization. Technocratic and planning-based project managers also had an impact on time and quality, since they relied on the proper planning, control and optimization. Each of the PMs' project management attitudes had an impact on the cost through proper planning of resources and resource allocation, but each had to consider a maximum, which they should not exceed. As a conclusion, project managers did have an impact on the project triangle. Each of the PMs' project management attitudes had an impact on client satisfaction as well. Strategic-oriented and stakeholder-centric project managers placed an emphasis on communication with the client and considered its demand. This increased the potential for achieving client satisfaction. At the same time, planning-based and technocratic project managers emphasized the importance of project triangle which realization increased the potential for client satisfaction. This latter interrelationship was mentioned by strategic-oriented and stakeholder-centric PMs also, but their primary tool for achieving client satisfaction was communication. Therefore, it can be concluded that the PM's attitude towards project management had an impact on the client satisfaction as well. Each of the PMs' project management attitudes had an impact on stakeholder satisfaction as well. Strategic-oriented and stakeholder-centric project managers used constant communication with the stakeholders and considered their interest. Technocratic and planning-based project managers placed less emphasis on communication, but the PMs dedicated considerable and enough time on communication also, in order to solve problems and motivate the project team leading to the realization of the project plans. Thus, project management attitude likewise had an impact on stakeholder satisfaction.

Concerning the outcomes, it can be concluded that the project manager's attitude has an impact on all the three success criteria. This outcome is summarized in the Table 2.

Table 2. Research outcomes of the impact of attitude on success criteria 


\begin{tabular}{|c|c|c|}
\hline $\begin{array}{l}\text { The adopted project } \\
\text { management attitude }\end{array}$ & Success criteria & Applied tools to achieve success \\
\hline \multirow{5}{*}{ Strategic-oriented } & time & $\begin{array}{l}\text { considering strategic goals } \\
\text { proper motivation }\end{array}$ \\
\hline & cost & resource allocation \\
\hline & quality & $\begin{array}{l}\text { considering strategic goals } \\
\text { proper motivation }\end{array}$ \\
\hline & client satisfaction & $\begin{array}{l}\text { considering strategic goals } \\
\text { communication } \\
\text { considering project triangle }\end{array}$ \\
\hline & stakeholder satisfaction & communication \\
\hline \multirow{5}{*}{ Stakeholder-centric } & time & $\begin{array}{l}\text { motivation } \\
\text { communication }\end{array}$ \\
\hline & cost & resource allocation \\
\hline & quality & $\begin{array}{l}\text { motivation } \\
\text { communication }\end{array}$ \\
\hline & client satisfaction & $\begin{array}{l}\text { communication } \\
\text { considering project triangle }\end{array}$ \\
\hline & stakeholder satisfaction & communication \\
\hline \multirow{5}{*}{ Technocracy } & time & planning, control, optimization \\
\hline & cost & resource allocation \\
\hline & quality & planning, control, optimization \\
\hline & client satisfaction & $\begin{array}{l}\text { communication } \\
\text { considering project triangle }\end{array}$ \\
\hline & stakeholder satisfaction & communication \\
\hline \multirow{5}{*}{ Planning-based } & time & planning, control, optimization \\
\hline & cost & resource allocation \\
\hline & quality & planning, control, optimization \\
\hline & client satisfaction & $\begin{array}{l}\text { communication } \\
\text { considering project triangle }\end{array}$ \\
\hline & stakeholder satisfaction & communication \\
\hline
\end{tabular}

Source: compilation of the author

\subsection{Impact of the project managers' personal characteristics on their adapted}

\section{leadership style}

The third step of the research highlights the existence of the impact of personal characteristics on the attitude and leadership styles. Throughout the first part of the third step, PMs were asked to define elements that contributed to their currently applied leadership style. Generally, in the first place, they mentioned the leadership style of a previous boss or one of their earlier project managers; yet their own personal characteristics were also emphasized. In addition education, trainings, family and organizational features were mentioned too, but less frequently than the previous elements. As for the leadership style, the interviewees mentioned particularly similar answers.

The following part of the third step focused on whether their personal characteristics (especially the six, which were noted in the literature review) had undergone changes during their professional career or not. With the exception of two PMs, they all stated that their 
personal characteristics altered during their project management career. The most remarkable change could be identified regarding their motivational skills and their emotional intelligence.

They were also asked to characterize their owned leadership style, both before and after the change in their personal characteristics. In case of no change, they were asked to characterize their current leadership style. They all indicated that at the beginning of their career they followed a more dictatorial leadership style, which might be categorized as a combination of leadership style based on traits and leadership style based on competency (cf. Müller - Turner $2007 ; 2010)$. When a change in personal characteristics was experienced, it involved a shift in the leadership style as well. A move from dictatorial leadership style towards a democratic leadership style could be identified. This can be categorized as a combination of leadership style based on emotional intelligence and leadership style based on behaviour and style (cf. Müller - Turner 2007; 2010). Those project managers who did not change regarding their personal characteristics, followed their earlier applied leadership style. Based on the finding of this part, it might be concluded that personal characteristics had an impact on the leadership style and the project management attitude as well.

The last question of the third step directly asked the interviewees whether they experienced the impact of their personal characteristics on their project management attitude and leadership style. The answers provided by the interviewees also reinforced the previously highlighted impact.

The outcomes of the field research confirm that the project management attitude has an impact on achieving project success expressed in terms of the three success criteria. At the same time it also might be concluded the personal characteristics have an impact on the attitude and the adopted leadership style.

\section{Conclusions}

It inevitably seems that project managers have a considerable impact on projects and a key role in achieving project success. Thus research analyzing their features could be important for increasing low success rate achieved on projects.

The aims of the research were to reveal the impact of project management attitude on both the three success criteria, and project manager's personal characteristics on project management attitude and leadership style. 
The field research justified the existence of these impacts. The project management attitude (strategic-orientated, stakeholder-centric, planning-based and technocratic) has an impact on the project triangle, client satisfaction and stakeholder satisfaction. This is due to the use of proper planning, control, optimization, communication and resource allocation. At the same time, personal characteristics have an impact on the project management attitude and leadership style. The latter is because project managers (by means of improvement of motivational skills and emotional intelligence) might shift their leadership style from a dictatorial to a more democratic style, which might increase the potential for achieving project success (cf. Blaskovics 2014). This is also reinforced by project managers, by mentioning personal characteristics as one of the main factors having an impact on their leadership style. Coincidentally, the impact of project management attitude is due to mentioning personal characteristics as one of the main factors having an impact on their project management attitude by project managers.

Concerning the research questions formulated in the 'Research and research methodology' section of the paper, we might conclude: a) the project management attitude has an impact on both three success criteria of the hierarchical model; b) the personal characteristics have an impact on leadership style and project management attitude. We need to emphasize again that the scale was not the focus of the research; instead, we focused on highlighting the existence of the impact itself.

Considering the research outcomes, we can also conclude that project management attitude and personal characteristics are highly important from the aspect of achieving success. Thus academic courses and training programs should place an emphasis on improving these features of the project manager. Although it should be mentioned, that in order to shape the project management attitude and personal characteristics, certain hard tools and techniques should be taught as well. Neglecting these tools and techniques, project management attitude and personal characteristics cannot be improved (cf. Cleland 1994). Thus, the appropriate combination of knowledge transfer and shaping of project management attitude and personal characteristics are desired to be developed.

The research outcomes are supported by the literature review, but only five companies with special features were considered during the research. Thus, the research outcomes cannot be generalized. They are valid for only those kinds of companies, which operate in a similar industry and having similar characteristics as the five companies. Further research should 
encompass analyzing more companies in the same industry, but with different characteristics or companies operating in a different industry.

The research is also facing other serious limitation: although the interrelationship was identified between personal characteristics and project management attitude and leadership style, other factors were not taken into consideration. Researchers did not try to identify every factor that has an impact on the latter two features of the project manager; and this research did not reveal factors which have an impact on both features of the project manager.

\section{REFERENCES}

Ahadzie, D. K. (2014): Competencies required of project managers at the design phase of mass house building projects. International Journal of Project Management 32(6): 958969.

Atkinson, R. (1999): Project management: cost, time and quality, two best guesses and a phenomenon, its time to accept other success criteria. International Journal of Project Management 17(6): 337-342.

Babbie, E.R. (1994): The practice of social research. Belmont: Wadsworth.

Baccarini, D. (1999): The Logical Framework Method for Defining Project Success. Project Management Journal 30(4): 25-32.

Blaskovics, B. (2014): Aspects of projects success - The case of a multinational company. PMUni Conference Vienna, 14 May.

Boynton, A.C. - Zmud, R.W. 1984. An Assessment of Critical Success Factors. Sloan Management Review 25(4): 17-27.

Bredillet, C (2007): From the Editor. Project Management Journal 38(2): 3-4.

Bryde, D.J. (2008): Perceptions of the impact of project sponsorship practices on project success. International Journal of Project Management 26(8): 800-809.

Cleland, D. I. (1994): Project Management - Strategic Design and Implementation (2nd ed.) New York: McGraw-Hill

Cooke-Davies, T. (2002): The "real" success factors on projects. International Journal of Project Management 20(3): 185-190. 
Creswell, J. W. (2003): Qualitative, Quantitative, and Mixed Methods Approaches. London: Sage.

Cserháti, G. - Szabó, L. (2014): The relationship between success criteria and success factors in organisational event projects. International Journal of Project Management 32(4): 613-624.

de Wit, A. (1988): Measurement of project success. International Journal of Project Management 6(3): 164-170.

Fehér, P. (2008): IT Stratégia [IT Strategy]. Lecture, 27.10.2008.

Fekete, I. - Dobreff, Cs. (2003): Távközlési projektmenedzsment [ICT project management]. Budapest: Múegyetemi Kiadó.

Fiedler, F. E. (1964): A Contingency Model of Leadership Effectiveness. Advances in experimental social psychology 1(1): 149-190.

Fortune, J. - White, D. (2006): Framing of project critical success factors by a system model. International Journal of Project Management 24(1): 53-65.

Görög, M. (1996): Általános projektmenedzsment [Project management in general]. Budapest: Aula Kiadó.

Görög, M. (2002): Strategy-oriented approach to project and the question of project success. Society and Economy 24(1): 55-68.

Görög, M. (2003): A projektvezetés mestersége [The profession of project management]. Budapest: Aula Kiadó.

Görög, M. (2013): Projektvezetés a szervezetekben [Organizational project management]. Budapest: Panem Könyvkiadó.

International Project Management Association (2014): The PE Model. http://ipma.ch. Accessed: 10.11.2014.

Jha, K.N. - Iyer, K.C. (2007): Commitment, coordination, competence and the iron triangle. International Journal of Project Management 25(5): 527-540.

Judgev, K. - Müller, R. (2005): A Retrospective Look at Our Evolving Understanging of Project Success. Project Managament Journal 36(4): 19-31.

Kun, E. (2005): Sydney Operaházának Felavatása [Opening of the Sydney Opera House]. http://www.geographic.hu/, accessed: 06.06.2014. 
Lee-Kelley, L. - Loong, K.L. (2003): Turner's five-functions of project-based management and situational leadership in IT services projects. International Journal of Project Management 21(8): 583-591.

Loo, R. (2002): Working towards best practices in project management: a Canadian study. International Journal of Project Management 20(2): 93-98.

Lundin, R. A. - Söderholm, J. (1995): A theory of the temporary organization. Scandinavian Journal of Management 11(4): 437-455.

Mészáros, T. (2005): A stratégia jövője - a jövő stratégiája [The future of strategy - the strategy of thefuture]. Budapest: Aula Kiadó.

Müller, R. - Turner, J. R. (2007): Matching the project manager's leadership style to project type. International Journal of Project Management 25(1): 21-32.

Müller, R. - Turner, R. (2010): Leadership competency profiles of successful project managers. International Journal of Project Management 28(7): 437-448.

Nemeslaki, A. - Duma, L. - Szántai Tamás, T. (2004): e-Business üzleti modellek [e-Business models]. Budapest: Adecom.

Olsen, R. P. (1971): Can project management be defined? Project Management Quarterly 2(1): 12-14.

Pant, I. - Baroudi, B. (2008): Project management education: The human skills imperative. International Journal of Project Management 26(2): 124-128.

Pettersen, N (1991): What do we know about the effective project manager? International Journal of Project Management 9(2): 99-104.

Pinto, J. K. (2000): Understanding the role of politics in successful project management. International Journal of Project Management 18(2): 85-91.

Project Management Institute (2006): Projektmenedzsment útmutató [Guide to project management]. Budapest: Akadémia kiadó.

Project Management Institute (2010): A guide to the Project Management Body of Knowledge. Newtown Square, Pennsylvania: PMI Publications.

Schaltegger, S. (2011): Sustainability as a driver for corporate economic success. Society and Economy 33(1): 15-28. 
Shenhar, A. J. - Dvir, D. - Levy, O. - Maltz, A. C. (2001): Project Success: A Multidimensional Strategic Concept. Long Range Planning 34(6): 699-725.

Standish Group (2013): The Chaos Manifesto: Think Big, Act Small. http://www.versionone.com/assets/img/files/CHAOSManifesto2013.pdf, accessed: 11.11.2014.

Toor, S. - Ogunlana, S. O. (2010): Beyond the ,iron triangle”: Stakeholder perception of key performance indicators (KPIs) for large-scale public sector development projects. International Journal of Project Management 28(3): 228-236.

Turner, J. R. (2009): Handbook of project based management: Leading strategic changes in organizations. New York: McGraw-Hill Professional.

Wateridge, J. (1997): How can IS/IT projects be measured for success? International Journal of Project Management 16(1): 55-63.

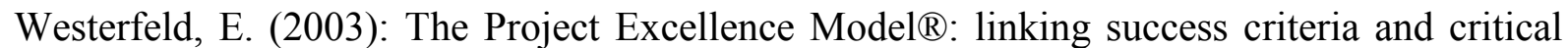
success factors. International Journal of Project Management 21(6): 411-418.

Yang, L. - Huang, C. - Wu, K. (2011): The association among project manager's leadership style, teamwork and project success. International Journal of Project Management 29(3): 258-267.

Yu, A. G. - Flett, P. D. - Bowers, J. A. (2005): Developing a value-centred proposal for assessing project success. International Journal of Project Management 23(6): 428-436. 